\title{
JUURNAL.RU
}

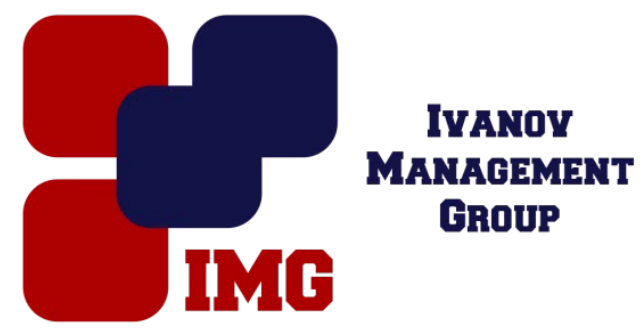

Александрова А.А. Поволжский государственный технологический университет Йошкар-Ола, Россия

doi: 10.18411/lj-30-11-2016-1-01

idsp 000001:lj-30-11-2016-1-01

\section{Развитие малого и среднего предпринимательства в России}

Научный руководитель: Родионова Е.В.

Развитие малого и среднего предпринимательства - это успешное движение вперёд, реализация того огромного творческого, созидательного предпринимательского потенциала, который, безусловно, есть у российского народа.

Малые и средние компании могут быстро занимать востребованные рыночные ниши, формировать новые точки экономического роста, способствовать эффективному развитию экономики, её эффективности, решению проблем занятости.

Страна должна способствовать развитию небольшого бизнеса. Механизмы экономической поддержки, которые созданы для развития малого и среднего бизнеса, разделяются на две группы: децентрализованные и централизованные. К первому виду принадлежат различные формы и методы саморегулирования малого бизнеса, а также его приспособления к условиям рыночной среды, которая постоянно меняется. Если говорить о централизованных механизмах, то к ним относятся мероприятия, связанные с созданием лучших условий для функционирования малого бизнеса. Основными целями, которые перед собой ставит государственная политика в области развития малого бизнеса в России, являются: 
1) создание условий, которые будут способствовать эффективной предпринимательской деятельности;

2) развитие малого бизнеса, как ключевого фактора для развития конкурентной среды, а также среднего класса общества;

3) увеличение процента занятости населения.

Меры, направленные на стимуляцию роста субъектов предпринимательской деятельности, а также на изменение отраслевой структуры средних и малых компаний, включают:

1) упрощение бюрократических процедур при ведении и регистрации бизнеса;

2) устранение неэффективного регулирования государства в сфере контроля и лицензирования;

3) совершенствование системы налогообложения для малых предприятий;

4) доступность различных форм финансирования для предпринимательской деятельности;

5) поддержка программ развития бизнеса, которые реализуются другими организациями.

Правительство нашего государства создало программу, которая нужна для поддержки малого предпринимательства в регионах. Оно помогает развивать бизнес-инкубаторы, создавать гарантийные и венчурные фонды, поддерживать предприятия, которые ориентированы на экспорт.

В России в целом созданы организационные и правовые основы государственной поддержки малого и среднего бизнеса, включая упрощённое налогообложение, систему грантов на открытие собственного дела, предоставление микрозаймов, гарантий, кредитов на льготных условиях. Расширяется доступ малого и среднего бизнеса к закупкам государственных компаний и компаний с госучастием. 


\section{Литература}

1. Бессолицын, А. А. История российского предпринимательства: учебник / А. А. Бессолицын. - 3-е изд., перераб. и доп. - М.: МФПУ Синергия, 2013. $400 \mathrm{c}$.

2. Голубева, Т.М. Основы предпринимательской деятельности: учебное пособие / Т.М. Голубева. - М.: Форум: НИЦ ИНФРА-М, 2013. - 272 с. 